\author{
Danuta Piróg \\ Uniwersytet Pedagogiczny \\ im. Komisji Edukacji Narodowej \\ w Krakowie
}

\title{
Kompetencje z zakresu przedsiębiorczości: rozważania teoretyczne i ich ilustracje w obszarze szkolnictwa wyższego
}

\section{Entrepreneurial competences: theoretical deliberations and their illustrations in higher education}

\begin{abstract}
Streszczenie
Kompetencje z zakresu przedsiębiorczości były i nadal są uznawane za istotny czynnik rozwoju społeczno-gospodarczego układów przestrzennych. Będąc znaczącym elementem kapitału ludzkiego, są one zarówno kluczową determinantą powstawania i efektywnego prosperowania przedsiębiorstw, a także pomyślnego wejścia na rynek pracy najemnej, jak i rozwijania kariery zawodowej. Badacze reprezentujący różne dyscypliny naukowe są zgodni, że w warunkach kryzysu gospodarczego i turbulentnego rynku pracy kompetencje te stanowią fundament efektywnego funkcjonowania jednostki w społeczeństwie na różnych płaszczyznach życia zawodowego i pozazawodowego.

Studia literatury jednoznacznie dowodzą, że kompetencje, które powszechnie uznawane są za odnoszące się do przedsiębiorczości, mają wybitnie eklektyczny charakter, co skutkuje pluralizmem pojęciowym i mnogością ich klasyfikacji.

Celem artykułu jest:

- dokonanie analizy wyników teoretycznych prac poświęconych kompetencjom z grupy przedsiębiorczość, ze szczególnym uwzględnieniem ich zakresu oraz roli we współczesnej wizji rozwoju społeczno-gospodarczego,

- egzemplifikacja nurtu kompetencyjnego w wyżej wymienionym zakresie w postkartezjańskim modelu uniwersytetu.
\end{abstract}

\footnotetext{
Abstract

Entrepreneurial competences have been and are still considered the crucial factor in socio-economic development. As a significant element of social capital, these competences are key factors in creating and developing new enterprises, a successful transition into the labour market, and furthering professional careers. Several socio-psychological studies prove that, in a period of economic crisis and turbulent labour market, entrepreneurial competences are responsible for the enhancement of people's social life activities.

The literature review shows various approaches towards research into entrepreneurial competence types. Therefore, the competences, which are commonly perceived as entrepreneurial, have a very eclectic character, i.e. they are defined in a variety of ways and categorised into a variety of groups. The aim of this article is to:

- Analyse various theoretical studies devoted to entrepreneurial competences/ business competences with a particular emphasis on their role in the current vision of socio-economic development;

- Exemplify this "entrepreneurial competence stream" in the previously mentioned aspects within a post-Cartesian university model.
} 
Słowa kluczowe: edukacja akademicka; kompetencje z zakresu przedsiębiorczości; rynek pracy; szkoła wyższa

Keywords: entrepreneurial competences; academic education; higher education; labour market; university

\section{Wstęp}

W rozważaniach dotyczących czynników rozwoju gospodarczego regionów w różnej skali układów przestrzennych szczególne miejsce zajmuje profesjonalizm, który wyraża się w zakresie opanowanych przez człowieka kompetencji i ich poziomie (Białasiewicz, 2008). Kapitał ludzki, a dokładnie jego jakość ujawniającą się głównie w kwalifikacjach, zastępuje się kapitałem opartym na wiedzy i umiejętnościach podmiotu (m.in.: Osuch, 2010; Bielecki, 2011; Górniak, 2014; Piróg, 2013b).

W Polsce wzrost naukowego zainteresowania kompetencjami w tym wymiarze rozpoczął się w latach 90. XX w. i w dużej mierze wynikał z transformacji gospodarki. Rodząca się wówczas gospodarka rynkowa generowała zapotrzebowanie na specjalistów mających umiejętności niezbędne do aktywnego uczestnictwa w poszczególnych etapach przemian. Należały do nich przede wszystkim: restrukturyzacja przemysłu, pojawianie się nowych typów przedsiębiorstw korporacyjnych, rozwój instytucji finansowych, banków i giełdy, proces integracji Polski z Unią Europejską oraz zmiany wynikające z nasilającej się globalizacji.

Przemiany gospodarcze spowodowały także, że kształcenie akademickie zaczęło się odbywać w warunkach rosnących aspiracji społeczeństwa w zakresie uzyskania wyższego wykształcenia, bowiem przez długi czas stanowiło ono gwarancję zdobycia atrakcyjnego zatrudnienia. Nieograniczony niemal dostęp do studiowania zwiększył prawdopodobieństwo wzrostu odsetka absolwentów, u których formalny dokument ukończenia uczelni wyższej - tradycyjnie świadczący o posiadaniu wysokiej jakości kompetencji - nie zawsze odzwierciedlał rzeczywistość (Sztanderska i in., 2005a,b) albo nie gwarantował nabycia takich umiejętności, które pozwalałyby im na stworzenie sobie miejsca pracy lub pozyskanie satysfakcjonującego zatrudnienia (Piróg, 2013a).

Od początku podjęcia badań dotyczących roli kompetencji w jakości funkcjonowania człowieka $\mathrm{w}$ społeczeństwie $\mathrm{w}$ różnych sferach życia publicznego i prywatnego, duże znaczenie zwłaszcza w aspekcie poruszania się przez niego na rynku pracy - przypisywano kompetencjom z zakresu przedsiębiorczości. Ich ważny wpływ na tempo rozwoju gospodarczego zaczęto mocno podkreślać podczas kryzysu. Kompetencje te są bowiem kluczowym czynnikiem powstawania oraz rozwoju indywidualnej działalności gospodarczej, kreowania nowych miejsc pracy, pomyślnego wejścia na rynek pracy najemnej czy budowania kariery zawodowej (McMillan, Woodruff, 2002; Mitchelmore, Rowley, 2010). Ponadto badania empiryczne wskazują, że są one w dużej mierze odpowiedzialne za jakość funkcjonowania jednostki na turbulentnym rynku pracy (Piróg, 2014).

Waga i skala kompetencji przedsiębiorczych w gospodarce opartej na wiedzy spowodowała, że stały się one przedmiotem badań i dyskusji specjalistów różnych dyscyplin. Odmienność perspektyw badawczych w procesie eksploracji tych zagadnień skutkuje zarówno różnym definiowaniem przedsiębiorczości, jak i kompetencji jej przynależnych (Gołębiowski, 2014).

Celem artykułu jest:

- dokonanie przeglądu teoretycznych prac poświęconych konceptualizacji kompetencji z zakresu przedsiębiorczości i próba syntezy zmierzającej do ukazania ewolucji pojęcia w ostatnim trzydziestoleciu,

- nakreślenie współczesnej roli wyższej edukacji w kształtowaniu kompetencji studentów wraz z egzemplifikacją nurtu kompetencyjnego w postkartezjańskim modelu uniwersytetu. 


\section{Kompetencje z zakresu przedsiębiorczości - różne oblicza i interpretacje}

Termin kompetencja ma wiele znaczeń i choć pojawił się w literaturze naukowej stosunkowo niedawno, stał się przedmiotem badań specjalistów, m.in. z zakresu pedagogiki pracy, polityki społecznej, ekonomii, socjologii, psychologii, zarządzania szkolnictwem wyższym oraz dydaktyki szkoły wyższej. Wielodziedzinowy charakter pojęcia kompetencja skutkuje mnogością spojrzeń na nie i w konsekwencji powstaniem wielu definicji, których pogłębiona analiza ujawnia jego eklektyzm. Różnorodność ta jest również związana ze współwystępowaniem dwóch sposobów rozumienia kompetencji, które w języku angielskim są odzwierciedlone za pomocą słów competency i competence. Pierwszy termin wywodzi się ze Stanów Zjednoczonych, gdzie kompetencje mają podłoże behawioralne i są ujmowane jako sposób zachowania, który wpływa na powodzenie wykonywanych zadań (Boyatizis, 1982 W: Strzebońska, Dobrzyńska, 2011). W tym rozumieniu kompetencje zbudowane są zazwyczaj ze składowych wiedzy, umiejętności i przejawianych postaw, które to postawy są uzewnętrznioną, wyuczoną - w różnych środowiskach - skłonnością człowieka do określonych zachowań i działań.

Inne rozumienie terminu kompetencje mieści się pod wyrazem competence. Termin ten, powstały na gruncie brytyjskim, skupia się na wystandaryzowanych wynikach wykonywanych działań, przypisanych np. do zawodu czy stanowiska pracy. Przy czym procedurze standaryzacji podlegają nie zachowania prowadzące do realizacji celu, ale efekty tych działań. Wymagane jest, aby wiedza, umiejętności i postawy wchodzące w zakres danej kompetencji były uszczegółowione w oparciu o ustalone i powszechnie dostępne kryteria (Mikuła, Pietruszka-Ortyl, 2007), np. efekty uczenia się przyjęte w Europejskich i Krajowych (Polskich) Ramach Kwalifikacji. Kompilacyjny charakter kompetencji, oprócz ryzyka nieścisłości terminologicznych, powoduje trudności w jednoznacznym określeniu, czy dane kompetencje są nabywane w procesie kształcenia - głównie wiedza, umiejętności, postawy - czy też są atrybutami i zdolnościami danej osoby. Cechą wspólną rozumienia kompetencji przez badaczy z wymienionych dyscyplin naukowych jest nawiązywanie do zachowań podmiotu, będących efektem współgrania ze sobą wiedzy, umiejętności i postaw. W tym triadowym ujęciu kompetencji wskazuje się, iż obejmują one zarówno zakresy nabyte, np. wiedzę, umiejętności, zakresy nabyte lub wrodzone, np.: otwartość, odpowiedzialność, jak i te, które mogą być wyłącznie wrodzone, czyli uzdolnienia.

W Polsce - mimo bardzo dużego zainteresowania naukowców problematyką kształcenia w zakresie przedsiębiorczości - stosunkowo skromne są badania dotyczące konceptualizacji tego pojęcia czy ustaleń, które kompetencje należy uznawać za fundamentalne dla osoby określanej mianem przedsiębiorczej. Dominują opracowania podnoszące kwestie kształtowania postaw przedsiębiorczych u uczniów na różnych szczeblach kształcenia (por.: Rachwał, 2005; Gabała, 2005; Błażejewski, 2006; Milewska, 2006; Borowiec, Rachwał, 2011). Należy jednak zaznaczyć, że charakterystyki postawy przedsiębiorczej w wymienionych opracowaniach w znacznej mierze opierają się na posiadanych przez podmiot kompetencjach. I tak np. Rachwał do cech odpowiedzialnych za wykształcenie postawy przedsiębiorczości zalicza m.in. kreatywność, skłonność do wyważonego ryzyka, gotowość do podejmowania nowych wyzwań (Rachwał, 2005). Podobnie Strojny uznał, że fundamentem osobowości przedsiębiorczej jest jej kreatywność i umiejętność rozwiązywania problemów (Strojny, 2007). Wszystkie składowe postawy przedsiębiorczej, nazwane wówczas cechami, dziś stanowią kanon kompetencji z zakresu przedsiębiorczości.

Dokonano także zestawienia kompetencji, które mogą być miarą przedsiębiorczości w odniesieniu do uczących się dzieci i młodzieży. Są to: komunikacja, współpraca, przedsiębiorczość, elastyczność, analiza potrzeb klientów, efektywność, niezależność, umiejętność rozwiązywania problemów, planowanie i organizowanie własnej pracy, kształcenie ustawiczne, panowanie nad stresem (Świłło, 2012: 73-74). Wskazano również na znaczenie kompetencji biznesowych, które mogą być budowane w szkolnictwie przez nabywanie wiedzy ekonomicznej, wiedzy i umiejętności 
związanych z prowadzeniem działalności gospodarczej, kompetencji społecznych oraz umiejętności osobistych, ze szczególnym naciskiem na postawę przedsiębiorczości (Kurek i in., 2012).

Kompetencje zaliczane do przedsiębiorczych były przedmiotem częstych teoretycznych i empirycznych eksploracji naukowych w literatury zagranicznej. Analiza interpretacji tego pojęcia przez różnych badaczy ujawnia różnorodność jego pojmowania, przede wszystkim pod względem zakresu pojęcia i spojrzenia na strategię nabywania tej grupy kompetencji (Markowska, 2011). U podstaw pluralizmu leży wielość perspektyw badawczych problematyki przedsiębiorczości w ogóle (perspektywa ekonomiczna, socjologiczna, psychologiczna, edukacyjna) oraz eklektyczny charakter kompetencji jako kategorii pojęciowej.

W latach 90. XX w., definiując kompetencje z zakresu przedsiębiorczości, podkreślano rolę kroków prowadzących do założenia indywidualnej działalności gospodarczej i skupiano się na kompetencjach menadżerskich oraz biznesowych. Dominowała orientacja na wiedzę człowieka w pięciu zakresach: wiem co, dlaczego, jak, kto, kiedy, która miała stanowić swoisty klucz do zrealizowania zadania, czyli otworzenia indywidualnej działalności gospodarczej. W wymienionych obszarach wiedzy niezbędne jest także zaistnienie umiejętności oraz postaw (np.: w komponencie wiem kto potrzebne są umiejętności społeczne, zaś w wiem kiedy - umiejętność planowania, przewidywania), ale najważniejszym efektem kształcenia są szeroko pojęte wiadomości (Johannisson, 1993).

Takie spojrzenie na kompetencje z zakresu przedsiębiorczości powodowało, że kształcenie nakierowane na ich osiągnięcie mogło być i było adresowane głównie do kierunków studiów dedykowanych problematyce ekonomicznej. Stosunkowo szybko zmiany zachodzące w gospodarce, procesy globalizacji i integracji stały się fundamentalnymi przesłankami do stwierdzenia, że kompetencje przedsiębiorcze powinny mieć znacznie szerszy zakres i nie mogą odnosić się jedynie do zakładania firmy. Stąd w definiowaniu kompetencji przedsiębiorczych zwrócono również uwagę na to, że istnieją umiejętności pozwalające przede wszystkim efektywnie realizować podjęte zadania, będące rezultatem wcześniejszej eksploracji potrzeb rynku (Chandler, Hanks, 1994). Podkreślono, że istotne są zarówno umiejętności zapewniające zauważenie potrzeby na rynku, jak i czynności prowadzące do wykorzystania szansy jej wypełnienia, np.: rozpoznawanie, przewidywanie, planowanie, wykorzystanie, pozyskanie (Erikson, 2002). Ta konceptualizacja pojęcia miała charakter instruktażu poszerzonego nie tylko w aspekcie zakresu, lecz także celu oraz strategii działania.

W literaturze można także się spotkać z definiowaniem kompetencji z zakresu przedsiębiorczości, które majoryzuje spojrzenie relacyjne. Pojęcie oparte jest na relacji między umiejętnościami związanymi ze zbudowaniem koncepcji służącej rozwojowi (rynku) a strategiami i organizacją działań umożliwiających jej zrealizowanie oraz poziomem zaangażowania jednostki w cały proces (Man i in., 2002).

Holistycznie i w sposób pogłębiony kompetencje z zakresu przedsiębiorczości pojmowała Bird. W ich definiowaniu badaczka zaakcentowała zagadnienie postaw oraz nakreśliła wiele umiejętności i cech jednostki, które powinna mieć osoba przedsiębiorcza. Swoje założenia oparła na współwystępowaniu wiedzy, umiejętności oraz postaw. W efekcie wyróżniła kompetencje na trzech poziomach:

- motywów i cech podmiotu (tolerancja, kontrola, gotowość do podejmowania ryzyka, wysoka motywacja do osiągania założonych celów),

- ról społecznych i koncepcji samego siebie (docenianie relacji międzyludzkich w kontekście biznesowym, troska o wysoką jakość pracy, asertywność, pewność siebie, stosunek do podejmowania działań prowadzących do pokonania trudności),

- wiedzy i umiejętności (podstawy finansów, rachunkowości, zarządzania, zasady skutecznego przywództwa, komunikacja) (Bird, 1995). 
Ostatnio w rozważaniach dotyczących kompetencji z zakresu przedsiębiorczości pojawiają się propozycje ich pojmowania jako umiejętności osiągania celów dzięki innowacyjnym sposobom postępowania, identyfikowania, przewidywania i wykorzystywania możliwości biznesowych. Poszukiwanie nowych ścieżek do osiągania celów, czyli nieszablonowych i skutecznych metod działań, powoduje, że za niezbędną kompetencję osoby przedsiębiorczej uznaje się przede wszystkim kreatywność i zdolność trafnej predykcji (Lans i in., 2010).

Cechą wspólną wszystkich analizowanych koncepcji kompetencji z zakresu przedsiębiorczości jest odniesienie się przez autorów do wybranych obszarów wiedzy, umiejętności i postaw jako dróg do nabywania tych kompetencji. Różnice ujawniają się w przypisywaniu wagi wyszczególnionym efektom kształcenia w procesie działań przedsiębiorczych oraz w proporcji komponentów wymienionej triady w strategii realizacji celów (tab. 1).

Tab. 1. Ewolucja konceptualizacji kompetencji z zakresu przedsiębiorczości

\begin{tabular}{|c|c|c|c|}
\hline Ujęcie & Akcent & $\begin{array}{c}\text { Relacje: wiedza, } \\
\text { umiejętności, } \\
\text { postawy }\end{array}$ & Przedstawiciele/Definicja \\
\hline instruktażowe & zadanie & wiedza & $\begin{array}{l}\text { Johannisson (1993) } \\
\text { Wiedza, która pozwala odpowiadać na pytania: } \\
\text { kto, kiedy, co, dlaczego, jak, oraz umiejętność } \\
\text { planowania, przewidywania nowych rzeczywisto- } \\
\text { ści (działalności gospodarczej) i sprawiania, że } \\
\text { staną się faktem. }\end{array}$ \\
\hline $\begin{array}{c}\text { instruktażowe } \\
\text { poszerzone }\end{array}$ & działanie & $\begin{array}{c}\text { wiedza }+ \\
\text { umiejętności }\end{array}$ & $\begin{array}{l}\text { Chandler, Hanks (1994); } \\
\text { Erikson (2002) } \\
\text { Umiejętność rozpoznania, przewidzenia, } \\
\text { zaplanowania i wykorzystania szansy połączona } \\
\text { z wiedzą na temat pozyskiwania zasobów. }\end{array}$ \\
\hline relacyjne & $\begin{array}{l}\text { relacje/ } \\
\text { interakcje }\end{array}$ & umiejętności & $\begin{array}{l}\text { Man i in. (2002) } \\
\text { Relacja między umiejętnością zbudowania } \\
\text { koncepcji rozwoju i strategiami działań umożli- } \\
\text { wiającymi jej zrealizowanie a poziomem } \\
\text { zaangażowania jednostki w proces (umiejętności } \\
\text { koncepcyjne, organizacyjne, strategiczne } \\
\text { i zaangażowanie). }\end{array}$ \\
\hline $\begin{array}{l}\text { pogłębione } \\
\text { triadowe }\end{array}$ & $\begin{array}{l}\text { współwy- } \\
\text { stępowanie }\end{array}$ & $\begin{array}{c}\text { wiedza }+ \\
\text { umiejętności }+ \\
\text { postawy }\end{array}$ & $\begin{array}{l}\text { Bird (1995) } \\
\text { Kompetencje obejmujące trzy sfery: } \\
\text { - motywów i cech podmiotu, } \\
\text { - ról społecznych i koncepcji samego siebie, } \\
\text { - wiedzy i umiejętności. }\end{array}$ \\
\hline $\begin{array}{l}\text { kreatywno- } \\
\text {-predykcyjne }\end{array}$ & $\begin{array}{l}\text { innowacja/ } \\
\text { nieszablo- } \\
\text { nowość }\end{array}$ & $\begin{array}{c}\text { umiejętności } \\
\text { (wyróżniające) }\end{array}$ & $\begin{array}{l}\text { Lans i in. (2010) } \\
\text { Umiejętności osiągania celów przez innowacyjne } \\
\text { sposoby postępowania, zwłaszcza identyfikowania, } \\
\text { przewidywania i wykorzystywania możliwości } \\
\text { (biznesowych). }\end{array}$ \\
\hline
\end{tabular}

Źródło: opracowanie własne. 
Oprócz prób zdefiniowania pojęcia kompetencji z zakresu przedsiębiorczości ustalono zestaw kompetencji, które charakteryzują osobę przedsiębiorczą. Najnowszą propozycją w tym zakresie, będącą efektem przeglądu bogatej literatury tematu, jest opracowanie autorstwa Mitchelmore i Rowley (2010). Zestawiły one 25 kompetencji, które inni specjaliści podejmujący tę problematykę najczęściej uwzględniali w swoich badaniach, i podzieliły je na kompetencje osobowościowe, osobiste oraz menadżerskie. W świetle tej pracy osoba, którą można określić mianem kompetentnej z zakresu przedsiębiorczości, powinna je mieć przynajmniej w podstawowym zakresie.

Pierwszą grupę stanowią kompetencje osobowościowe. Najczęściej pojmowane są one jako te umiejętności, które decydują o skuteczności funkcjonowania jednostki w różnych sytuacjach - ściśle wiążą się z cechami osobowości i mogą być wykształcane dzięki treningowi społecznemu. Do kluczowych kompetencji z zakresu przedsiębiorczości z tej grupy zaliczono siedem umiejętności lub postaw. Najważniejsze znaczenie ma pewność siebie rozumiana jako mocna i realistyczna wiara w swoje predyspozycje oraz kompetencje. W tym ujęciu stanowi ona podstawę do przekonania o możliwości osiągania postawionych celów oraz do gotowości do podejmowania decyzji, co determinuje efektywność każdego działania realizowanego zarówno w roli przedsiębiorcy, jak i wartościowego pracownika najemnego. Z nią ściśle wiąże się umiejętność samooceny, która z kolei została wskazana jako podstawa do budowania i rozwoju pozytywnego wizerunku oraz szacunku do samego siebie. Za niezbędną kompetencję osobowościową uznano radzenie sobie z trudnościami pojmowane jako duch walki, niepoddawanie się w sytuacji niepowodzenia i wyciąganie wniosków z porażki. Osoba posiadająca tę kompetencję ma pełną świadomość, że niepowodzenie to naturalny etap w rozwoju, nieodłączny element w dążeniu do sukcesu, kreujący sposobność do wyższej efektywności w przyszłości. W działaniach przedsiębiorczych konieczna jest otwartość wobec szeroko pojętej różnorodności, odmiennych poglądów, stanowisk, filozofii działania, dlatego podkreślono znaczenie tolerancji. Kolejne kompetencje z tej grupy to: autoprezentacja, troska o wysoką jakość i poczucie umiejscowienia kontroli (ang. LOC, Locus of Control). Pierwsza z nich oznacza umiejętność zaprezentowania siebie i swoich pomysłów w sposób pozytywnie wyróżniający się w porównaniu z innymi osobami. Druga dotyczy sytuacji, kiedy osoba wykonująca produkt czy usługę ma potrzebę i umiejętność wykonania jej w jakości oczekiwanej, a nawet przewyższającej założone standardy (lepiej, szybciej, taniej, dokładniej). Trzecia to umiejętność opanowania, samokontroli, niepoddawania się wpływom i naciskom.

Najliczniejszy zbiór tworzą kompetencje behawioralne, do których zalicza się dziesięć różnych umiejętności i postaw. Należy do nich wola sukcesu, czyli umiejętność motywowania siebie i innych do podejmowania wyzwań, nowych zadań, rozwiązywania pojawiających się trudności oraz problemów. Człowiek przedsiębiorczy musi mieć również umiejętność podejmowania ryzyka, która polega na zdolności decydowania w sytuacji niepewności i akceptowania ewentualnych niepożądanych konsekwencji swojej decyzji. Kluczowe jest podejmowanie ryzyka, z którego skutkami dana osoba jest w stanie sobie poradzić. Powinna temu towarzyszyć wytrwałość rozumiana jako konsekwentne i pełne zaangażowania realizowanie celów mimo napotkanych trudności oraz witalność i energia, czyli stała gotowość do działań, ruchu, wysiłku, które także mają służyć osiąganiu założonych rezultatów.

Kompetencje przedsiębiorcze buduje również inicjatywność, która oznacza aktywność wyrażoną gotowością i rzeczywistym podejmowaniem różnych zadań, braniem odpowiedzialności, realizowaniem większego zakresu działań niż wynika to z podstawowych obowiązków. Bliskie, 
ale nie tożsame z wcześniej wymienionymi, są dwie kolejne kompetencje, czyli innowacyjność oraz kreatywność. Innowacyjność jest stałym poszukiwaniem nietypowych rozwiązań, wprowadzaniem zmian, które są praktyczne i skuteczne. Kreatywność to umiejętność zidentyfikowania luki na rynku i wymyślenia sposobu na to, aby ją wypełnić. Obejmuje to także robienie dobrze znanych rzeczy w nowy sposób. Z kreatywnością wiąże się kolejna kompetencja - poszukiwanie i wykorzystywanie szans, czyli szczególna, wyróżniająca kogoś umiejętność oraz intuicja, tzw. nos do odkrywania nowych pól do działania.

Do podgrupy kompetencji behawioralnych zaliczono także asertywność i potrzebę autonomii. Asertywność w zakresie kompetencji przedsiębiorczych definiowana jest jako umiejętność świadomego korzystania ze swojego prawa do obrony i zachowywania własnych potrzeb bez agresji, przemocy czy używania swojej pozycji w pełnym poszanowaniu innych osób. Potrzeba autonomii to kompetencja ujawniająca się w przejmowaniu kontroli, przewodzeniu grupie tak, by zaakceptowała naszą koncepcję działań i nasze argumenty. Niekiedy potrzeba autonomii i kontroli może grozić przyjęciem postawy dyktatora. Aby tego uniknąć, osoba przedsiębiorcza musi mieć bardzo wysoką potrzebę osiągania celów i sukcesów przy niskim pragnieniu władzy.

Kompetencje menadżerskie związane są z zarządzaniem pracownikami lub współpracą w zespole. Dotyczą one zarówno kompetencji miękkich, z zakresu kierowania oraz organizacji pracy, jak i kompetencji specjalistycznych - odnoszących się do konkretnych zakresów wiedzy fachowej. Bardzo ważna jest umiejętność formułowania celów i wytrwałość, czyli jasne i zrozumiałe werbalizowanie celów działań oraz dążenie do ich realizacji pomimo trudności. Konieczne są w tym procesie wytężona praca, cierpliwość, wytrzymałość, spokój, opanowanie i nieokazywanie niezadowolenia. Tej kompetencji powinna towarzyszyć kolejna, czyli poszukiwanie informacji. Oznacza ona umiejętność rzetelnego zgromadzenia potrzebnych danych, które są niezbędne do podjęcia trafnej decyzji. Jako ważną kompetencję menadżerską wskazano systematyczne planowanie, czyli przygotowywanie przemyślanego planu realizacji każdego działania, oraz rozwiązywanie problemów polegające na wykorzystaniu swojej wiedzy i umiejętności do pokonania zarówno drobnych przeszkód, jak i złożonych trudności, wynikających w toku realizowania celów.

Człowiek przedsiębiorczy powinien także mieć wysokie kompetencje interpersonalne, czyli umieć dostrzegać i szanować potrzeby innych osób, właściwie wyrażać uczucia i emocje, być świadomym i czuć potrzebę robienia dobrego wrażenia. Umiejętność ta to również dostosowywanie swoich działań do różnych kontekstów społecznych. Kompetencje interpersonalne pozostają w ścisłej zależności z kolejnymi dwiema umiejętnościami, tj.: perswazją oraz komunikowaniem się. Perswazja w kontekście kompetencji przedsiębiorczych jest umiejętnością przekonywania innych osób czy całych grup - współpracowników, kontrahentów, klientów do swojego produktu, pomysłu. Komunikowanie się to zdolność transferu idei, planów, pomysłów do pracodawców, pracowników, współpracowników czy klientów tak, by mieli poczucie pełnej świadomości i jasności tychże.

Dynamiczne zmiany w każdej dziedzinie życia, w tym w obszarze innowacji, powodują również konieczność posiadania obycia technicznego, czyli umiejętności podążania za zmianami technologicznymi, dokształcania się w tym zakresie, poszerzania znajomości najnowszych i powszechnie stosowanych rozwiązań technologicznych (Mitchelmore, Rowley, 2010) (tab. 2). 
Tab. 2. Klasyfikacja kompetencji z zakresu przedsiębiorczości

\begin{tabular}{|c|c|c|}
\hline \multicolumn{3}{|c|}{ Kompetencje } \\
\hline osobowościowe (społeczne) & behawioralne (osobiste) & menadżerskie \\
\hline $\begin{array}{l}\text { - pewność siebie } \\
\text { - poczucie umiejscowienia } \\
\text { kontroli } \\
\text { - radzenie sobie } \\
\text { z trudnościami } \\
\text { - tolerancja } \\
\text { - troska o wysoką jakość } \\
\text { - umiejętność autoprezentacji } \\
\text { - umiejętność samooceny }\end{array}$ & $\begin{array}{l}\text { - } \text { asertywność } \\
\text { - gotowość do podejmowania } \\
\text { ryzyka } \\
\text { - inicjatywność } \\
\text { - kreatywność } \\
\text { - potrzeba autonomii } \\
\text { - umiejętność poszukiwania } \\
\text { i wykorzystywania szans } \\
\text { - umiejętność podejmowania } \\
\text { ryzyka } \\
\text { - witalność i energia } \\
\text { - wola sukcesu } \\
\text { - wytrwałość }\end{array}$ & $\begin{array}{l}\text { - komunikacja interpersonalna } \\
\text { - umiejętność formułowania } \\
\text { celów } \\
\text { - umiejętność komunikowania się } \\
\text { - umiejętność perswazji } \\
\text { - umiejętność poszukiwania } \\
\text { informacji } \\
\text { - umiejętność rozwiązywania } \\
\text { problemów } \\
\text { - umiejętność systematycznego } \\
\text { planowania } \\
\text { - obycie techniczne }\end{array}$ \\
\hline
\end{tabular}

Źródło: opracowanie własne na podstawie S. Mitchelmore, J. Rowley, 2010.

\section{Kompetencje z zakresu przedsiębiorczości w obszarze szkolnictwa wyższego}

Uznanie zasadności rozwijania różnych kompetencji, w tym przedsiębiorczych, u młodzieży akademickiej oraz rzeczywiste wdrażanie takiej wizji kształcenia na szczeblu wyższym to konsekwencją oddziaływania wielu czynników. Jednym z nich jest wskazanie w dokumentach unijnych potrzeby rozwijania kompetencji przedsiębiorczych u młodzieży akademickiej. W zaleceniu Parlamentu Europejskiego i Rady Europy z 18 grudnia 2006 r. w sprawie kompetencji kluczowych w procesie uczenia się przez całe życie do kompetencji transferowalnych zaliczono: porozumiewanie się w języku ojczystym, porozumiewanie się w językach obcych, kompetencje matematyczne i podstawowe kompetencje naukowo-techniczne, kompetencje informatyczne, umiejętność uczenia się, kompetencje społeczne i obywatelskie, świadomość i ekspresję kultur oraz poczucie inicjatywy i przedsiębiorczość.

Kolejny czynnik to wdrażanie Krajowych Ram Kwalifikacji, które obecnie odbywa się na wszystkich uczelniach wyższych. Fundamentem tej koncepcji jest skoncentrowanie się w projektowaniu planów i programów na efektach kształcenia, do których należą kompetencje.

Zainteresowaniu szkolnictwa wyższego włączaniem kompetencji z zakresu przedsiębiorczości do puli efektów kształcenia - zarówno do programu nauczania, jak i do poszczególnych kursów - sprzyja zachodząca transformacja uniwersytetu z modelu kartezjańskiego na postkartezjański (Jałowiecki, 1998). W pierwszym z wymienionych modeli nauka jest uprawiana dla czystego poznania i realizacji wewnętrznych celów środowiska naukowego. W drugim głównym celem nauki jest jej aplikacyjny charakter, a wyniki badań są kierowane do określonych odbiorców. Koncentracja uwagi przesuwa się z celów wewnętrznych na zewnętrzne, czyli na zaspokajanie potrzeb społeczeństwa. Wielość tychże i złożony charakter warunków życia społecznego indukują potrzebę badań interdyscyplinarnych. Zaczynają się rozwijać nauki pogranicza. To z kolei uruchamia zmiany modelu powiązań między naukowcami w procesie badawczym z hierarchicznego w kierunku hierarchii horyzontalnej, ponieważ znaczącą rolę zaczyna odgrywać współpraca międzynarodowa. Konstruowanie międzynarodowych grup badaczy ekspertów jest elementem tworzenia jednolitego systemu kształcenia, np. w Unii Europejskiej. Wskazane uwarunkowania wywołują potrzebę i zarazem stwarzają klimat do wykształcenia znacznie bardziej różnorodnych kompetencji wśród naukowców i studentów. 
Kolejnym bodźcem do kształcenia w tym zakresie na uniwersytetach są aktualne realia rynku pracy, które wymuszają na absolwentach umiejętność konkurowania w celu pozyskania zatrudnienia lub założenie własnej działalności gospodarczej i starania, aby przynosiła ona oczekiwane zyski. Jak wskazują badania, wiele z kompetencji zaliczanych w literaturze tematu do przedsiębiorczych należy do tych, które będą niezbędne pracownikowi albo przedsiębiorcy na rynku pracy w niedalekiej przyszłości (Górniak, 2014).

Wreszcie, istotnym czynnikiem wpływającym na prawdopodobny wzrost zainteresowania szkolnictwa wyższego kompetencjami z zakresu przedsiębiorczości są wyniki badań naukowych. Te dowiodły, że edukacja - zwłaszcza na poziomie wyższym - znacznie bardziej niż doświadczenie pracy jest źródłem i pierwotnym bodźcem do wykształcenia kompetencji przedsiębiorczych. Zwłaszcza innowacyjność i inicjatywność są tymi umiejętnościami, które stanowią fundament przedsiębiorczości i ściśle zależą od ukończonego etapu edukacji (Maxwell, Westerfield, 2002).

Uznaniu potrzeby wykształcenia kompetencji przedsiębiorczych w szkole wyższej powinno towarzyszyć określenie, które z nich są niezbędne do efektywnego funkcjonowania absolwenta na rynku pracy i mogą być rozwijane na każdych studiach wyższych - bez względu na ich kierunek. Jak wskazują międzynarodowe badania ${ }^{1}$ dotyczące tego zagadnienia, przedstawiciele pracodawców oraz naukowców byli ze sobą w tym zakresie częściowo zgodni. Zarówno naukowcy, jak i przedsiębiorcy wskazali po dwie te same kompetencje jako najistotniejsze (w pierwszej piątce), czyli: innowacyjne myślenie oraz podejmowanie decyzji, jedną tę samą kompetencję jako bardzo istotną (w drugiej piątce), tj.: skuteczne negocjowanie, i odpowiednio trzy te same kompetencje jako ważne (w trzeciej piątce), czyli: budowanie zespołu, intuicję oraz podejmowanie wyważonego ryzyka. Generalnie akademicy przypisywali wymienionym kompetencjom niższe znaczenie niż pracodawcy. Przykładowo przedsiębiorcy wskazali podejmowanie decyzji na pierwszym miejscu, a akademicy na trzecim; przedsiębiorcy przypisali drugie miejsce innowacyjnemu myśleniu, a nauczyciele uczelni wyższych - pozycję piątą (tab. 3).

Obie grupy respondentów wskazały osiem kompetencji z zakresu przedsiębiorczości, które ich zdaniem - powinny być opanowane w toku edukacji na poziomie wyższym, bez względu na kierunek kształcenia. Są to:

- budowanie zespołu,

- innowacyjne myślenie,

- komunikacja,

- ocena możliwości biznesowych,

- podejmowanie decyzji,

- rozpoznawanie i rozwiązywanie problemów,

- rozpoznawanie możliwości biznesowych,

- umiejętność negocjacji (Izquierdo, Deschoolmeester, 2010).

Przedsiębiorcy uznali te umiejętności za fundamentalne lub jedne z ważniejszych w każdym rodzaju pracy i w różnych regionach świata. Nauczyciele akademiccy ocenili je jako właściwe dla kształcenia na szczeblu wyższym i na tyle uniwersalne, aby mogły być osiągane w obrębie studiów na każdym kierunku.

Tworzenie warunków do uświadamiania posiadanych i nabywania nowych kompetencji przedsiębiorczych w szkołach wyższych powinno się odbywać w trojaki sposób, tj. przez:

- nauczanie - uczenie się o przedsiębiorczości (teaching “about” entrepreneurship),

\footnotetext{
${ }^{1}$ Badaniami objęto 1870 firm o różnym stażu, różnej wielkości i odmiennym profilu oraz 60 pracowników naukowych z 30 krajów.
} 
Tab. 3. Kompetencje z zakresu przedsiębiorczości a szkolnictwo wyższe: ilustracje empiryczne

\begin{tabular}{|l|l|}
\hline \multicolumn{1}{|c|}{$\begin{array}{c}\text { Opinie pracowników naukowych } \\
\text { (nauczycieli akademickich) }\end{array}$} & \multicolumn{1}{|c|}{ Opinie przedsiębiorców } \\
\hline 1. Poszukiwanie szans biznesowych & 1. Podejmowanie decyzji \\
2. Ocena szans biznesowych & 2. Innowacyjne myślenie \\
3. Podejmowanie decyzji & 3. Wykrywanie i rozwiązywanie problemów \\
4. Współpraca & 4. Szeroki pogląd rynku (znajomość) \\
5. Innowacyjne myślenie & 5. Komunikacja \\
& \\
6. Wykrywanie i rozwiązywanie problemów & 6. Skuteczne negocjowanie \\
7. Radzenie sobie z niepewnością & 7. Poszukiwanie szans biznesowych \\
8. Komunikacja & 8. Ocena szans biznesowych \\
9. Skuteczne negocjowanie & 9. Współpraca \\
10. Radzenie sobie ze stresem & 10. Współpraca w grupie \\
& \\
11. Podejmowanie wyważonego ryzyka & 11. Budowanie zespołu \\
12. Budowanie zespołu & 12. Intuicja \\
13. Intuicja & 13. Radzenie sobie z niepewnością \\
14. Szeroki pogląd rynku (znajomość) & 14. Radzenie sobie ze stresem \\
15. Współpraca w grupie & 15. Podejmowanie wyważonego ryzyka \\
\hline
\end{tabular}

Źródło: Izquierdo i in., 2005; Izquierdo, Deschoolmeester, 2010.

- nauczanie - uczenie się dla przedsiębiorczości (for entrepreneurship),

- nauczanie - uczenie się przez przedsiębiorczość (through entrepreneurship).

Wybór jednej strategii lub wykorzystanie ich wszystkich w dowolnych kombinacjach, jednocześnie bądź modułowo, zależy od stopnia i profilu kształcenia. Zakłada się, że każdy student, bez względu na kierunek studiów, powinien - przede wszystkim przez właściwy dobór metod kształcenia - mieć stworzone warunki do nabywania formalnych kompetencji przedsiębiorczych, tj.: innowacyjności, kreatywności, komunikacji społecznej, współpracy w zespole, rozwiązywania problemów (Lackeus, 2013). Im lepiej te kompetencje zostaną przez niego opanowane, tym rzetelniej jest przygotowany do dorosłego życia w aspekcie stworzenia sobie miejsca pracy, poszukiwania i skutecznego pozyskania pracy najemnej, rozwoju kariery zawodowej i rozwoju osobistego.

\section{Podsumowanie}

Przedstawiony w niniejszym artykule przegląd literatury ujawnił lukę w polskim piśmiennictwie, dotyczącą aktualnej próby konceptualizacji pojęcia kompetencji z zakresu przedsiębiorczości. Wskazane wydaje się zatem nasilenie badań teoretycznych, realizowanych na styku nauk społeczno-ekonomicznych oraz dydaktyki szkoły wyższej, które zaowocowałyby pogłębioną, multidyscyplinarną refleksją polskich badaczy nad tym zagadnieniem w kontekście wcześniejszych ustaleń specjalistów z innych krajów. Działanie to mogłoby się przyczynić do upowszechnienia przekonania różnych środowisk dydaktyczno-naukowych o zasadności wykształcania kompetencji z zakresu przedsiębiorczości na szczeblu wyższym i do wdrożenia tej koncepcji w realia praktyki edukacyjnej na uniwersytetach.

Poziom wykształcanych u studentów kompetencji jest tzw. niematerialnym zasobem uczelni, narzędziem w konkurowaniu o nowych kandydatów na studia w danej jednostce. Upowszechnianie informacji o ich zakresie i poziomie może być stymulowane przez zewnętrznych interesariuszy szkolnictwa wyższego, tj. kandydatów na studia, studentów, absolwentów, inne uczelnie 
wyższe, komisje akredytacyjne, państwo, samorządy lokalne i pracodawców (Bielecki, 2011). Krajowe Ramy Kwalifikacji jednoznacznie odnoszą się do wiedzy, umiejętności i kompetencji jako podstawowych trzech rezultatów procesu edukacyjnego. Kompetencje stają się standardem w konstrukcji i realizacji kształcenia na poziomie wyższym, są podstawą do zatrudnienia potencjalnych pracowników przez pracodawców oraz zakładania własnej działalności gospodarczej. Rosnąca świadomość studentów i naukowców-nauczycieli akademickich o roli umiejętności nabywanych na studiach w budowaniu konkurencyjności absolwenta na rynku pracy i jakości jego funkcjonowania w dorosłym życiu może spowodować, iż ta grupa efektów kształcenia wyższego ma ogromną szansę na rzeczywiste, trwałe zafunkcjonowanie w filozofii edukacji uniwersyteckiej w Polsce.

\section{Literatura \\ References}

Białasiewicz, M. (2008). Przedsiębiorczość - pożądana kompetencja. Studia i Prace Wydziału Nauk Ekonomicznych i Zarządzania Uniwersytetu Szczecińskiego, 1, 7-16.

Bielecki, P. (2011). Kompetencje absolwentów studiów wyższych w świetle ogólnoeuropejskich badań CHEERS, REFLEX i TUNNG. W: K. Jędralska, K. Bernais (red.), Kompetencje absolwentów studiów ekonomicznych. Perspektywa nauki i biznesu. Katowice: Wydawnictwo Uniwersytetu Ekonomicznego w Katowicach, 13-66.

Bird, B. (1995). Towards a theory of entrepreneurial competency. W: J.A. Katz, R.H. Brockhaus (red.), Advances in entrepreneurship, firm emergence and growth. Greenwich: CT: JAI Press, 51-72.

Błażejewski, W. (2006). Problemy rozwoju postaw przedsiębiorczych u gimnazjalistów. Przedsiębiorczość - Edukacja, 2, 242-248.

Borowiec, M., Rachwał, T. (2011). Kształtowanie postaw przedsiębiorczych na lekcjach geografii wyzwaniem edukacyjnym w procesach globalizacji. Przedsiębiorczość - Edukacja, 7, 321-332.

Boyatzis, R.E. (1982). The competent manager: a model for effective performance. London: Wiley.

Chandler, G., Hanks, S. (1994). Founder Competence, the Environment, and Venture Performance. Entrepreneurship Theory \& Practice. 18 (3), 77-89.

Erikson, T. (2002). Entrepreneurial capital: the emerging venture's most important asset and competitive advantage. Journal of Business Venturing, 17, 275-290. DOI: 10.1016/S0883-9026(00)00062-8

Gabała, J. (2005). Kształtowanie postaw przedsiębiorczych uczniów. Przedsiębiorczość - Edukacja, 1, $145-152$.

Gołębiowski, G. (2014). Przedsiębiorczość w Polsce w świetle badań Global Entrepreneurship Monitor. Studia BAS, 1(37), 9-25.

Górniak, J. (red) (2014). Kompetencje Polaków a potrzeby polskiej gospodarki. Raport podsumowujący $I V$ edycje badań BKL z 2013 r. Warszawa: PARP.

Izquierdo, E., Deschoolmeester, D., Salazar, D. (2005). The importance of competencies for entrepreneurship: A view from entrepreneurs and scholars'perspective. Pozyskano z: http://www.espae.espol.edu. ec/images/documentos/publicaciones/documentos_trabajo/entrepreneurship/Importance.pdf (ostatni dostęp: 2014, 20 października)

Izquierdo, E., Deschoolmeester, D. (2010). What Entrepreneurial Competencies should be emphasized in Entrepreneurship and Innovation Education at the Undergraduate Level? W: A. Fayolle (red.), Handbook of Research on Entrepreneurship Education: International Perspectives, 3. Gheltenham, UK: Edward Elgar Publishing.

Jałowiecki, B. (1998). Rola uniwersytetu w rozwoju regionalnym. Zagadnienia Naukoznawstwa, 4(138). 
Johannisson, B. (1993). Entrepreneurial Competence and Learning Strategies. W: R. Larsson, L. Bengtsson, K. Eneroth, A. Malm (red.), Research in Strategic Change. Lund: Lund University Press, 77-99.

Kurek, S., Rachwał, T., Szubert, M. (2012). Kształtowanie kompetencji biznesowych uczniów gimnazjum W świetle opinii nauczycieli na podstawie wyników badań prowadzonych w ramach europejskiego projektu FIFOBI, Przedsiębiorczość - Edukacja, 8, 24-36.

Lackeus, M. (2013). Developing entrepreneurial competencies. An action-based approach and classification in entrepreneurial education. Chalmers University of Technology, Gothenburg, Sweden. Pozyskano z: http://vcplist.com/wp-content/uploads/2013/11/Lackeus-Licentiate-Thesis-2013-DevelopingEntrepreneurial-Competencies.pdf

Lans, T., Biemans, H., Mulder, M., Verstegen, J. (2010). Self-awareness of mastery and improvability of entrepreneurial competence in small businesses in the agrifood sector. Human Resource Development Quarterly, 21(2), 147-168. DOI: 10.1002/hrdq.20041

McMillan, J., Woodruff, Ch. (2002). The central role of entrepreneurs in transition economies. Journal of Economics Perspectives, 16(3), 153-170. DOI: 10.1257/089533002760278767

Man, T., Lau, T., Chan, K.F. (2002). The competitiveness of small and medium enterprises. A conceptualization with focus on entrepreneurial competencies. Journal of Business Venturing, 17(2), 123-142.

Markowska, M. (2011). Entrepreneurial Competence Development. Triggers, Processes \& Consequences. JIBS Dissertation Series No. 071. Pozyskano z: http://www.diva-portal.org/smash/get/diva2:458043/ FULLTEXT02.pdf

Maxwell, J.R., Westerfield, D.L. (2002). Technological entrepreneurism: characteristics related to the adoption of innovative technology. SAM Advanced Management Journal, 67(1), 9-21.

Mikuła, B., Pietruszka-Ortyl, A. (2007). Kompetencje pracowników w perspektywie strategicznego zarządzania wiedzą w przedsiębiorstwie. Zeszyty Naukowe Akademii Ekonomicznej w Krakowie, 747, 52.

Milewska, M. (2006). Rozbudzanie postaw przedsiębiorczych wśród młodzieży wiejskiej. Przedsiębiorczość - Edukacja, 2, 249-255.

Mitchelmore, S., Rowley, J. (2010). Entrepreneurial competencies: a literature review and development agenda. International Journal of Entrepreneurial Behaviour \& Research, 16(2), 92-111.

Osuch, W. (2010). Kompetencje przedmiotowe i dydaktyczne nauczycieli geografii oraz studentów geografii-kandydatów na nauczycieli. Kraków: Wyd. Naukowe UP.

Piróg, D. (2013a). Absolwenci szkół wyższych na rynku pracy w warunkach kryzysu. Przedsiębiorczość -Edukacja, 9, 302-316.

Piróg, D. (2013b). Wybrane determinanty tranzycji absolwentów studiów wyższych na rynek pracy. Dylematy współczesnego rynku pracy. Studia Ekonomiczne. Zeszyty Naukowe Wydziałowe UE w Katowicach, 160, 131-138.

Piróg, D. (2014). The impact of degree programme educational capital on the transition of graduates to the labour market. Studies in Higher Education, 1-15. DOI:10.1080/03075079.2014.914916

Rachwał, T. (2005). Kształtowanie postaw u uczniów na lekcjach podstaw przedsiębiorczości. Przedsiębiorczość - Edukacja, 1, 137-144.

Strojny, J. (2007). Kształtowanie postawy przedsiębiorczej - procesy socjalizacji i autokreacji. W: P. Wachowiak, M. Dąbrowski, B. Majewski (red.), Kształtowanie postaw przedsiębiorczych a edukacja ekonomiczna. Warszawa: FPiAKE, 205-211.

Strzebońska, A., Dobrzyńska, M. (2011). Kompetencje jako przejaw kapitału ludzkiego. W: J. Górniak (red.), Bilans kapitału ludzkiego w Polsce. Raport podsumowujący pierwsza edycję badań realizowana w 2011 roku. Warszawa: PARP, 26-39.

Sztanderska, U., Minkiewicz, B., Bąba, M. (2005a). Absolwent na rynku pracy. Forum Akademickie, 6.

Sztanderska, U., Minkiewicz, B., Bąba, M. (2005b). Absolwent na rynku pracy. II, Forum Akademickie, 7-8.

Świłło, I. (2012). Jestem przedsiębiorczy - kształtowanie postaw przedsiębiorczych wśród młodzieży z wykorzystaniem innowacyjnych technik i narzędzi”. Prezentacja projektu. Przedsiębiorczość - Edukacja, 8, 71-77. 
Danuta Piróg, dr, adiunkt w Instytucie Geografii Uniwersytetu Pedagogicznego im. KEN w Krakowie. Jej zainteresowania naukowe dotyczą przede wszystkim zróżnicowania kulturowego Europy i tożsamości jej mieszkańców, przygotowania kandydatów na nauczycieli geografii i przyrody do przyszłej pracy zawodowej oraz efektywności studiów geograficznych w aspekcie potrzeb rynku pracy. Swoje doświadczenie naukowe pogłębiała przez czynny udział w krajowych i międzynarodowych projektach badawczych lub kierowanie nimi. Aktualnie zajmuje się głównie wielowymiarowymi analizami czynników warunkujących procesy tranzycji absolwentów szkół wyższych na rynek pracy.

Danuta Piróg, $\mathrm{PhD}$, an assistant professor at the Pedagogical University of Cracow (Institute of Geography). Her research interests are focus on intercultural education, European education, practical preparation of students (candidates for the geography teaching profession) and the effectiveness of geographical studies in the context of the needs of the labour market. She has been a member of various scientific projects on national and European level. Currently her scientific surveys are devoted to multidimensional analysis of determinants of HE graduates transition into the labour market.

Adres/Address: Uniwersytet Pedagogiczny im. Komisji Edukacji Narodowej w Krakowie Instytut Geografii

ul. Podchorążych 2

30-084 Kraków, Polska

e-mail: dbutryn@up.krakow.pl 